WARSZTATY Z GEOGRAFII TURYZMU

ISBN 978-83-7525-925-4 $\quad$ s. 287-306

http://dx.doi.org/10.18778/7525-925-4.20

Krzysztof KOŁODZIEJCZYK

Uniwersytet Wrocławski

\title{
SZLAKI TURYSTYCZNE PRZYSTOSOWANE DO POTRZEB OSÓB NIEPEŁNOSPRAWNYCH - DOŚWIADCZENIA POLSKIE I CZESKIE, PRÓBA STWORZENIA WZORCA
}

\section{Wprowadzenie}

Tematyka przystosowania szlaków turystycznych do potrzeb osób niepełnosprawnych została w Europie Środkowej zauważona stosunkowo niedawno, jednak jest $\mathrm{w}$ ostatnim czasie coraz częściej podejmowana ${ }^{1}$ i pojawiają się pierwsze próby realizacji przedstawianych postulatów. Wiąże się to z coraz powszechniejszą w ostatnich latach tendencją by odchodzić od traktowania osób niepełnosprawnych jako potrzebujących ciągłej opieki, a postrzegać je jako pełnowartościowych członków społeczeństwa, którzy - pod warunkiem stworzenia takiej możliwości - będą aktywnie uczestniczyć w życiu społecznym, uczyć się i pracować, co pozwoli na ich samorealizację. Takie konieczne obecnie podejście wynika stąd, że - według szacunków Rady Europy - ludzie z różnymi rodzajami niepełnosprawności stanowią już około 10-15\% ogółu społeczeństwa, a liczba ta będzie zapewne nadal rosnąć na skutek wydłużania się średniej długości życia (ZAZDROŻNY 2009).

\footnotetext{
${ }^{1}$ Dowodem może być uczynienie z turystyki górskiej osób niepełnosprawnych tematu przewodniego numeru 2/2012 kwartalnika "Tatry".
} 
Jednym z przejawów uczestnictwa w życiu społecznym jest turystyka, a w jej ramach szczególne znaczenie powinna mieć turystyka aktywna, do uprawiania której zachętą mogą być odpowiednio przygotowane szlaki.

Szlaki turystyczne to oznakowane w specjalny sposób ścieżki i drogi udostępniające z reguły obszary najbardziej atrakcyjne pod względem turystycznym, a przynajmniej doprowadzające do wielu walorów krajoznawczych. Polskie Towarzystwo Turystyczno-Krajoznawcze definiuje je jako „wytyczoną w terenie trasę, służącą do odbywania wycieczek, oznakowaną jednolitymi znakami i wyposażoną w urządzenia informacyjne, które zapewniają bezpieczne i spokojne jej przebycie turyście o dowolnym poziomie umiejętności i doświadczenia, o każdej porze roku, w każdych warunkach pogodowych, o ile szczególne wymagania nie stanowią inaczej" (Instrukcja... 2007). T. LIJEWSKI, B. MIKUŁOWSKI i J. WYRZYKOWSKI (2002) zwracają uwagę na konkretne warunki, aby dana trasa mogła być uznana za szlak turystyczny. Wśród nich najważniejsze z perspektywy turystyki osób niepełnosprawnych to: konieczność zapewnienia sposobu prowadzenia nie budzącego wątpliwości co do przebiegu trasy oraz zapewnienie bezpieczeństwa $\mathrm{w}$ różnych warunkach atmosferycznych turystom o zróżnicowanym poziomie umiejętności i wydolności organizmu. Dla osób niepełnosprawnych ważne jest jednak nie tylko samo zapewnienie bezpieczeństwa, ale w ogóle umożliwienie korzystania ze szlaku poprzez odpowiednie jego wybudowanie bądź przystosowanie. Szlaki powinny być także powiązane $\mathrm{z}$ siecią schronisk oraz komunikacją zbiorowa, które również powinny być odpowiednio przystosowane dla niepełnosprawnych turystów, tak by mogli nie tylko przebyć szlak, ale też przenocować, a co najważniejsze - do niego dojechać.

Szlaki dla niepełnosprawnych często podświadomie kojarzone są z osobami na wózkach inwalidzkich, trzeba jednak pamiętać o osobach z innymi rodzajami schorzenia, którzy potrzebują odmiennych przystosowań, a również powinni mieć możliwość korzystania ze szlaków turystycznych. Można wyróżnić następujące rodzaje niepełnosprawności (tab. 1) (ZAZDROŻNY 2009):

- niepełnosprawność sensoryczna - dotycząca wzroku lub słuchu;

- niepełnosprawność fizyczno-motoryczna - dotycząca narządów ruchu lub wynikająca ze schorzeń narządów wewnętrznych;

- niepełnosprawność psychiczna - wynikająca z upośledzenia umysłowego, niepełnosprawności intelektualnej, choroby psychicznej, epilepsji; 
- niepełnosprawność społeczna - wynikająca z zaburzenia równowagi nerwowej, emocjonalnej i zdrowia psychicznego.

Liczbę osób niepełnosprawnych w Polsce posiadających odpowiednie orzeczenie określa się na ponad 4450 tys. (niepełnoprawni prawnie), a tych bez orzeczenia na ponad $1 \mathrm{mln}$ (niepełnosprawni biologicznie). Według danych GUS, blisko 30\% populacji ma różnego rodzaju problemy ze wzrokiem (ZAZDROŻNY 2009). Czyni to potężną grupę potencjalnych uczestników turystyki, którzy zwykle są pozbawieni takiej możliwości bądź z przyczyn technicznych (niezależnych od niepełnosprawnych, ale jak najbardziej zależnych od decyzji i działań pełnosprawnych), bądź psychicznych (zależnych od niepełnosprawnych, jednak znaczący wpływ na przełamywanie barier mają odpowiednie ułatwienia i nastawienie osób pełnosprawnych). Turystyka osób niepełnosprawnych w Polsce dopiero zaczyna się rozwijać. Zdecydowana większość osób z różnego rodzaju trwałymi schorzeniami w ogóle nie uczestniczy $\mathrm{w}$ turystyce, turystykę krajową podejmuje - zależnie od grupy - 15-21\%, a turystykę zagraniczną - nie więcej niż 1\% niepełnosprawnych (SKALSKA 2004). Podejmowane podróże skupiają się na dużych miastach i najważniejszych kulturowych walorach krajoznawczych, które są lepiej dostosowane do potrzeb niepełnosprawnych, natomiast omijają słabiej zagospodarowaną prowincję i tereny górskie, uznawane za gorzej dostępne.

Tabela 1. Struktura (w \%) osób niepełnosprawnych w wieku 15 lat i więcej według schorzeń powodujących niepełnosprawność w 2004 r. (dane nie sumują się do 100\%, ponieważ jednej osoby może dotyczyć więcej niż jedna przyczyna niepełnosprawności)

\begin{tabular}{|l|c|c|c|}
\hline \multicolumn{1}{|c|}{ Wyszczególnienie } & Ogółem & 15-59 lat & $\begin{array}{c}60 \\
\text { i więcej lat }\end{array}$ \\
\hline Uszkodzenia i choroby narządów ruchu & 46,1 & 41,9 & 50,2 \\
Uszkodzenia i choroby narządu wzroku & 29,5 & 22,4 & 36,5 \\
Uszkodzenia i choroby narządu słuchu & 13,9 & 8,3 & 19,4 \\
Schorzenia układu krążenia & 48,5 & 37,1 & 59,7 \\
Schorzenia neurologiczne & 29,0 & 30,9 & 27,2 \\
Schorzenia psychiczne & 7,9 & 11,3 & 4,4 \\
Upośledzenie umysłowe & 2,5 & 4,1 & 1,0 \\
Inne schorzenia & 26,2 & 25,9 & 26,6 \\
\hline
\end{tabular}

Źródło: P. ZAZDROŻNY (2009).

Szlaki turystyczne przystosowane do potrzeb osób niepełnosprawnych są w Polsce i w Republice Czeskiej (podobnie jak w całej Europie Środkowej) nadal nieliczne, stanowiąc często prekursorskie projekty, nie zawsze w pełni 
udane, ale przyjmowane z uznaniem i entuzjazmem wśród tej grupy turystów. W artykule poddano analizie kilka takich tras $\mathrm{z}$ terenu południowej Polski oraz jeden projekt czeski, by ostatecznie dokonać próby wypracowania wzorca. Zawarte $\mathrm{w}$ artykule informacje oparto na badaniach terenowych przeprowadzonych w okresach letnich 2011 i 2012 r.

\section{Doświadczenia polskie}

\subsection{Karkonosze}

W Karkonoskim Parku Narodowym przygotowano dwie trasy przystosowane do potrzeb osób niepełnosprawnych, przy czym uwzględniono tylko potrzeby niepełnosprawnych ruchowo. Park nie posiada obecnie w ogóle oferty skierowanej do osób z innymi upośledzeniami. Brak takich tras ogranicza tym grupom możliwość pełnego zapoznania się $\mathrm{z}$ walorami terenu. Może to wynikać z niechęci do wprowadzania w krajobraz Karkonoszy kolejnych elementów infrastruktury turystycznej, zwłaszcza biorąc pod uwagę obecny wysoki poziom zainwestowania tych gór. Warto jednak podkreślić, że przygotowanie tras dla osób niesłyszących nie wymaga budowy żadnych wyróżniających się w krajobrazie obiektów, a może polegać tylko na przygotowaniu odpowiedniej liczby elektronicznych przewodników (audio-guide, iGuide), które można by wypożyczyć w punktach wejścia na szlaki. Natomiast niewidomym wystarczą popularne tablice dydaktyczne wzbogacone o tekst pismem Braille'a. Ponadto przygotowane już odcinki szlaków dla osób na wózkach inwalidzkich mają inną nawierzchnię i metalowe poręcze, wyróżniają się więc w krajobrazie, co przeciwstawia się powyższej tezie. Władze parku podzieliły szlaki leżące na jego terenie na trzy grupy (mając na uwadze głównie osoby poruszające się na wózkach inwalidzkich): łatwe do przystosowania dla niepełnosprawnych, wymagające większych nakładów finansowych i pracy oraz w ogóle nienadające się do takiego przystosowania. W oparciu o tę kategoryzację mają być podejmowane kolejne inwestycje.

Starszą z dwóch przygotowanych tras jest ścieżka dydaktyczna z parkingu w dolinie Kamiennej poniżej Szklarskiej Poręby do wodospadu Szklarki. Ma ona 373 m długości, przy różnicy wzniesień 11 m i najwięk- 
szym nachyleniu 17\%, co znacznie przewyższa zalecane normy. Zgodnie z przyjętą praktyką na podjazdach dłuższych niż 1,5 m nachylenie podłużne nie powinno bowiem przekraczać $6 \%{ }^{2}$, co umożliwia poruszanie się niepełnosprawnym zarówno wózkami klasycznymi, jak i elektrycznymi. W przypadku podjazdu dłuższego niż $9 \mathrm{~m}$ konieczne jest zastosowanie spocznika o długości co najmniej 1,4 m (ZAZDROŻNY 2009). Nachylenie poprzeczne ścieżki nie powinno natomiast przekraczać 2-6\% (General Design Guidelines... 2007). Szlak do wodospadu Szklarki ma szerokość około $2 \mathrm{~m}$ (przy zalecanej szerokości co najmniej 1,2 m), a jego nawierzchnia pokryta jest plastikową siatką dzięki czemu nie jest śliska, nawet wtedy kiedy jest mokra, tak by osobom poruszającym się po niej (niepełnosprawnym i pełnosprawnym) nie groził poślizg ani upadek ${ }^{3}$. Od strony potoku trasę zabezpieczono barierkami z poręczą na wysokości odpowiedniej dla osób na wózkach. Ścieżkę wyposażono w zatoczki-mijanki, a na jej końcu, przy wodospadzie i schronisku turystycznym „Kochanówka” znajduje się metalowy podest widokowy. Parter schroniska jest również przystosowany dla osób poruszających się na wózkach inwalidzkich, jednak występują tu pewne ograniczenia. Na trasie przygotowano trzy punkty dydaktyczne $z$ tablicami oraz tzw. ogród zmysłów. Głównym mankamentem trasy - poza zbyt dużymi nachyleniami, co zmusza do korzystania z pomocy opiekuna - jest parking, przy którym się ona zaczyna. Ze względu na jego niewielką powierzchnię wyznaczono tu mało miejsc postojowych dla niepełnosprawnych, a popularność wodospadu Szklarki powoduje, że parking jest z reguły przepełniony. Dojście do początku trasy utrudniają liczne stragany z pamiątkami.

Nowsza trasa dostępna dla osób na wózkach inwalidzkich wiedzie z kolei od górnej stacji wyciągu krzesełkowego na Kopę ku Równi pod Śnieżką kończąc się po nieco ponad 1 km obok schroniska „Dom Śląski” (rys. 1). Jej utworzenie powiązano $\mathrm{z}$ przygotowaniem obejścia zniszczonego przez erozję fragmentu Śląskiej Drogi po południowo-zachodniej stronie Kotła Łomniczki. Wyremontowano nawierzchnię i wzdłuż całego odcinka wybu-

\footnotetext{
${ }^{2}$ Niektóre źródła podają wartość 5\% (m.in. General Design Guidelines... 2007).

${ }^{3} \mathrm{Z}$ perspektywy osób poruszających się na wózkach inwalidzkich nawierzchnia jest tym lepsza, im jest równiejsza, przy czym takie rozwiązanie jest niebezpieczne dla osób pełnosprawnych, zwłaszcza po opadzie deszczu lub śniegu, bądź gdy na podłożu utworzy się lód. W takich warunkach idealnie wyrównana nawierzchnia może stanowić też przeszkodę i zagrożenie dla osób na wózkach. By pogodzić potrzeby obu grup, ścieżki wyrównuje się, zachowując jednak porowatość podłoża (np. poprzez stosowanie plastikowych siatek).
} 


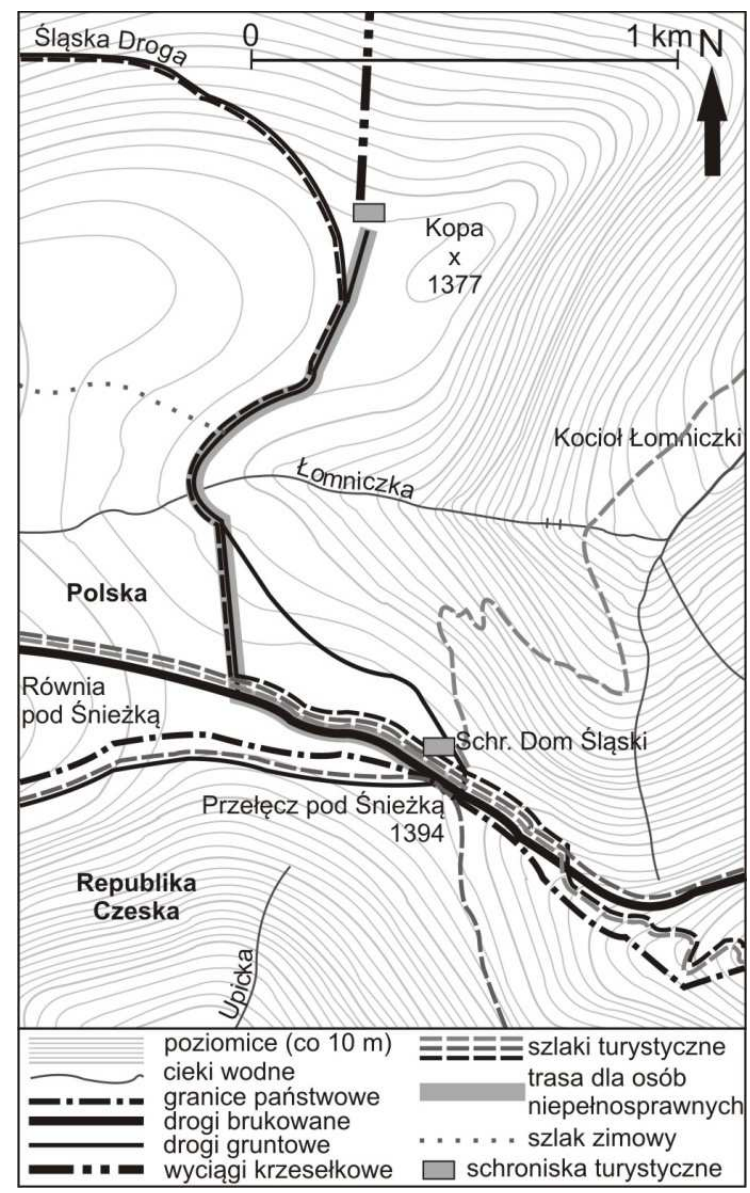

Rys. 1. Trasa dostępna dla osób na wózkach inwalidzkich z Kopy na Przełęcz pod Śnieżką na tle ukształtowania terenu i sieci innych szlaków turystycznych Źródło: opracowanie własne

dowano pas dla niepełnosprawnych o szerokości około 1,5 m, wyłożony podobną siatką jak w przypadku ścieżki do wodospadu Szklarki i wyposażony w metalową barierkę (fot. 1). Pozbawiona tablic dydaktycznych trasa, o nieznacznych nachyleniach odpowiadających zaleceniom, ma wyprowadzać w rejon Śnieżki niepełnosprawnych turystów, którzy wjechali w najwyższą część Karkonoszy wyciągiem krzesełkowym. Niestety zasadniczym problemem $\mathrm{w}$ funkcjonowaniu trasy są znaczące ograniczenia w przewozie osób na wózkach inwalidzkich przez wyciąg w jego dotychczasowej formie. 
Po przeprowadzonym remoncie przewóz niepełnosprawnych ma być jednak wyraźnie ułatwiony.

Wyżej opisane szlaki dla niepełnosprawnych w parku narodowym to nie wszystkie tego typu trasy w Karkonoszach. Starsza od nich trasa znajduje się poza obszarem chronionym, w północno-wschodniej części masywu, powyżej centralnej części Kowar. Szlak oznaczony jest symbolami osoby na wózku inwalidzkim, jednak oznaczenia są zniszczone, wobec czego trudno w pełni odtworzyć przebieg trasy, jak również nie można uznać, że pełnią one funkcję prowadzenia turysty. Szlak zapewne pokrywa się z Leśną Ścieżką Przyrodniczo-Edukacyjną "Jedlinki", która wiedzie z miejsca piknikowego powyżej dawnej stacji kolejowej Kowary Średnie przez Jedlinki do Krzaczyny. Ścieżka w całości ma nawierzchnię asfaltową i z reguły nieznaczne nachylenia, a wyposażono ją w 12 stanowisk dydaktycznych. Niestety o żadnej $z$ opisanych specjalnych tras nie znajdziemy informacji na stronie internetowej parku narodowego, jedyną wzmiankę o szlaku do wodospadu Szklarki autor znalazł na odwrocie mapy turystycznej Karkonoski Park Narodowy, cz. 1, przygotowanej przez Wydawnictwo Turystyczne „Plan” i dołączonej kilka lat temu do „Gazety Wrocławskiej”.

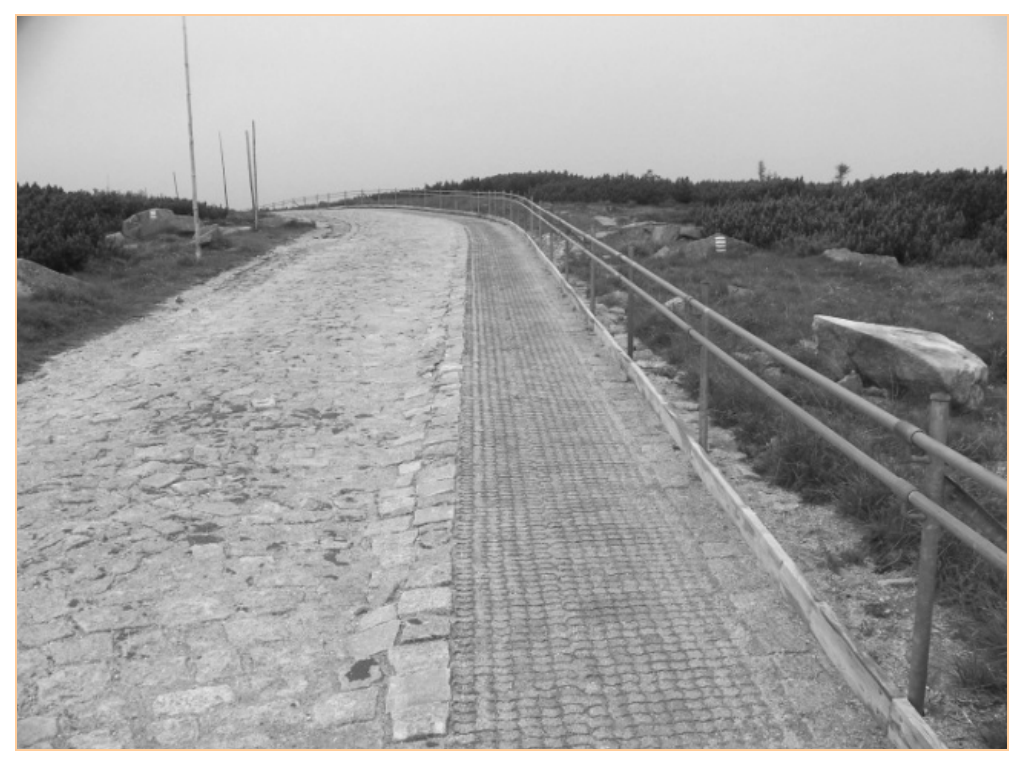

Fot. 1. Wyłożony siatką pas dla osób poruszających się na wózkach inwalidzkich na Równi pod Śnieżką (fot. K. Kołodziejczyk, 2012) 


\subsection{Góry Suche}

Z inicjatywy lokalnej społeczności, na wschód od Sokołowska, powstała ścieżka dydaktyczna z 12 tablicami, na których typowa treść została wzbogacona informacjami w piśmie Braille'a i przestrzennymi (płaskorzeźbionymi) elementami przeznaczonymi dla osób z uszkodzonym lub chorym narządem wzroku (fot. 2). Ścieżka ma formę pętli prowadzącej z Sokołowska, dnem doliny potoku Czertowiec, do Rozdroża pod Krzywuchą a następnie południowym zboczem doliny z powrotem do Sokołowska. Od Rozdroża pod Krzywuchą prowadzi jeszcze ślepo zakończony odcinek ścieżki do schroniska „Andrzejówka” (rys. 2). Każda z tablic dydaktycznych ma nalepkę z tekstem pisanym brajlem. Niestety pierwotne nalepki okazały się nietrwałe i obecnie są sukcesywnie wymieniane, jednak podczas badań (lipiec 2012 r.) część tablic była ich pozbawiona. Poza tym na każdej tablicy znajduje się przestrzenny element, który może być odkrywany dotykiem, ale jest również użyteczny dla osób widzących, stanowiąc uzupełnienie treści przekazanych drukiem i załączonych zdjęć. Na pierwszym stanowisku jest to prosta mapa okolicy oddająca główne rysy ukształtowania terenu (niestety także

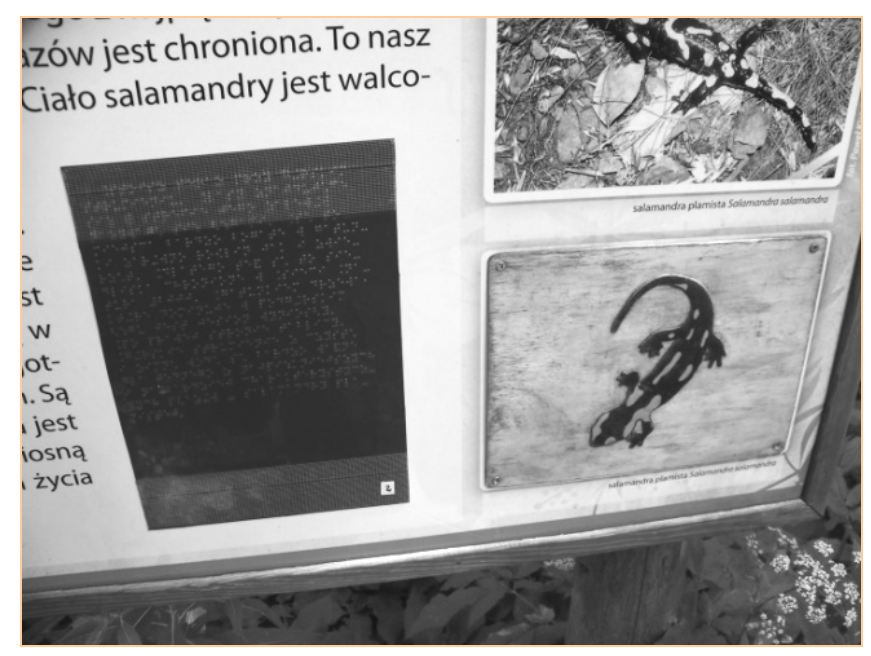

Fot. 2. Plakietka z pismem Braille'a i płaskorzeźbione wyobrażenie salamandry plamistej na jednej z tablic ścieżki dydaktycznej w okolicach Sokołowska (fot. K. Kołodziejczyk, 2012) 
została wykonana złą techniką i jest trochę zniszczona), na kolejnych - płaskorzeźbione sylwetki zwierząt, tropy niektórych z nich, liście drzew, podobizny roślin oraz pobliskich ruin zamku Radosno i cerkwi w Sokołowsku.

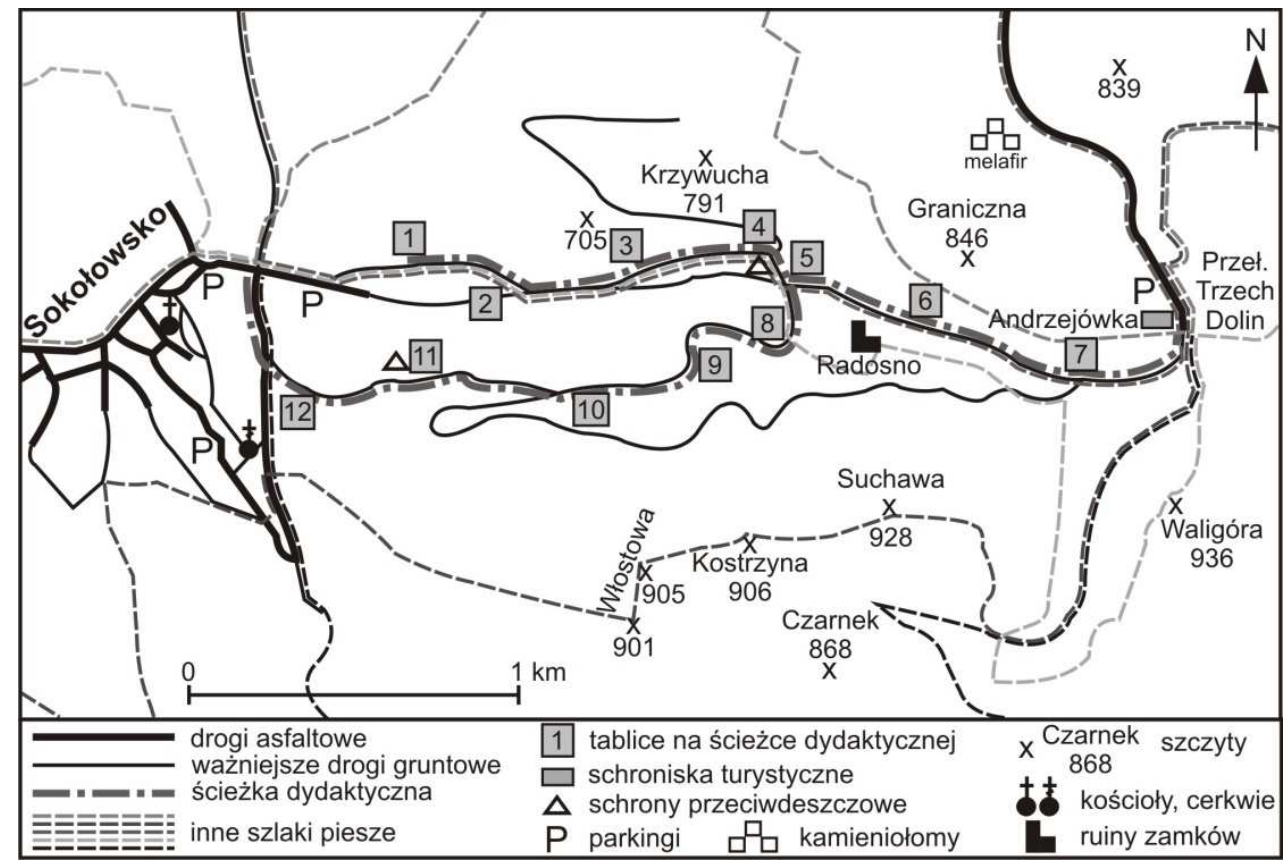

Rys. 2. Ścieżka dydaktyczna w Górach Suchych przystosowana do potrzeb osób z uszkodzonym narządem wzroku Źródło: opracowanie własne

Z wyjątkiem początkowego i końcowego odcinka o nawierzchni asfaltowej ścieżka dydaktyczna wiedzie szerokimi drogami gruntowymi, stąd osoby niewidome $\mathrm{z}$ pomocą opiekuna lub wyszkolonego psa przewodnika nie będą miały problemu z jej przebyciem. Trasa nie jest jednak dostępna dla turystów poruszających się na wózkach inwalidzkich, głównie ze względu na nie zawsze równą nawierzchnię drogi (czasem jest to luźny grys), rynny odwadniające i znaczne nachylenie kilku fragmentów, zwłaszcza bocznicy do schroniska "Andrzejówka”. Ewentualnie, przy większym wysiłku, trasę może pokonać osoba na wózku z pomocą opiekuna. Na Rozdrożu pod Krzywuchą oraz na końcowym odcinku przed Sokołowskiem znajdują się obszer- 
ne wiaty ze stołami i ławami oraz miejscem na ognisko. Niestety tylko pierwsza z nich, leżąca bliżej szlaku, jest dostępna dla niepełnosprawnych, ścieżka prowadząca do drugiej jest zbyt silnie nachylona. Stoły z ławami znajdują się również przy schronisku „Andrzejówka”. O ścieżce brak informacji w terenie, publikacjach i Internecie. $Z$ centrum Sokołowska nie prowadzą do jej początku żadne kierunkowskazy, w efekcie czego trafia się na nią przypadkowo, wędrując zielonym lub żółtym szlakiem w kierunku Przełęczy Trzech Dolin. Pierwsza tablica ustawiona jest na skraju Parku Krajobrazowego Sudetów Wałbrzyskich, w odległości około $300 \mathrm{~m}$ od najbliższego miejsca postojowego i $700 \mathrm{~m}$ od centrum miejscowości (a tym samym większego skupienia miejsc parkingowych). Tablica początkowa powinna zostać zainstalowana także od strony schroniska "Andrzejówka”, gdzie znajduje się duży parking i skąd większość turystów rozpoczyna wędrówki po Górach Suchych, tym bardziej że przystanki ścieżki mogą być odkrywane w dowolnej kolejności.

\subsection{Góry Stołowe}

W Parku Narodowym Gór Stołowych na potrzeby osób z uszkodzonym narządem wzroku została przystosowana krótka ścieżka edukacyjna „Niknąca łąka”, znajdująca się we wschodniej części parku. Ścieżka, o długości nieco ponad $300 \mathrm{~m}$, poprowadzona jest po drewnianych kładkach z obu stron ograniczonych barierkami i ukazuje walory silnie zdegradowanego torfowiska wysokiego, które od 2002 r. podlega restytucji. Oprócz kilku zwykłych tablic dydaktycznych na początku i na końcu ścieżki zainstalowano na słupkach wysokości nieco ponad $1 \mathrm{~m}$ dwie niewielkie tablice $\mathrm{z}$ treścią pisana brajlem dotyczącą występujących tu roślin. By ułatwić korzystanie z tablic, umocowano je pod kątem $45^{\circ}$. Powierzchnia każdej tablicy w całości pokryta jest pismem punktowym, a w tle znajdują się duże zdjęcia omawianych gatunków.

Kładka, którą prowadzi ścieżka edukacyjna ma wyrównaną powierzchnię, bez schodków, z łagodnymi podjazdami na obu krańcach, dzięki czemu osoby niewidome mogą się po niej wygodnie poruszać, a barierki uniemożliwiają zejście ze ścieżki na grząskie podłoże. Kładka jest na tyle szeroka, że jeździć po niej mogą również osoby na wózkach inwalidzkich. Pewne zastrzeżenia budzi jednak to, że niektóre deski pod wpływem warunków 
atmosferycznych uległy odkształceniu, co może skutkować potknięciem się i utrudnia przejazd. Niepełnosprawni na ścieżce muszą więc pozostawać pod stałą opieką. Głównymi zastrzeżeniami wobec omawianej trasy jest jej położenie $\mathrm{z}$ dala od parkingów (najbliższy $\mathrm{w}$ odległości 2,5 km krętym szlakiem o nierównej nawierzchni, najbliżej samochodem można dojechać $1 \mathrm{~km}$ od ścieżki, skąd prowadzi do niej wygodny dukt, lecz brak tam miejsc postojowych) oraz brak informacji o tym przystosowaniu (w terenie, w publikacjach, jak i w Internecie, w tym na stronie parku narodowego). Można mieć wątpliwości, czy niewidomi dowiedzą się o przygotowanej dla nich trasie i czy będą w stanie do niej dotrzeć.

\subsection{Szlak Orlich Gniazd}

Obecnie trwają prace na wyznaczeniem i oznakowaniem wariantu Szlaku Orlich Gniazd dla osób poruszających się na wózkach inwalidzkich, a chcących przebyć jego dłuższy fragment. Ponieważ w dużej części szlak biegnie drogami asfaltowymi, innego przebiegu wymagają tylko niektóre odcinki. $\mathrm{Z}$ drugiej strony, $\mathrm{w}$ ostatnich latach zmieniono przebieg pewnych fragmentów szlaku tak, by zmniejszyć długość trasy wiodącej asfaltem. Dotyczy to m.in. odcinka od zamku w Ojcowie do zamku Pieskowa Skała, gdzie szlak obecnie kilkakrotnie wspina się na zbocze doliny Prądnika, podczas gdy pierwotnie przebiegał drogą asfaltową jej dnem. Niestety, nie zawsze wariant dla niepełnosprawnych może wieść starym przebiegiem szlaku, a to głównie ze względu na dużą ruchliwość niektórych szos (m.in. drogi wojewódzkiej u podnóża zamku Pieskowa Skała).

Fragmenty szlaku wiodące bocznymi drogami asfaltowymi są już w obecnej sytuacji dostępne dla osób na wózkach inwalidzkich, przy czym muszą one dotrzeć na trasę własnymi samochodami. Przygotowano nawet propozycje wycieczek skierowane do omawianej grupy turystów, jednak bardzo słaba jest ich promocja. Wiele do życzenia pozostawia też inna infrastruktura, zwłaszcza noclegowa i gastronomiczna, która jednak w ostatnim czasie coraz lepiej się rozwija. Pozytywnie wyróżniają się w tym względzie Podlesice leżące w pobliżu Kroczyc. Większość tutejszych obiektów turystycznych jest przystosowana do obsługi osób niepełnosprawnych, osoby poruszające się na wózkach może gościć też wiele kwater prywatnych w sąsiednich Rzędkowicach oraz Podzamczu koło Ogrodzieńca. Problemem po- 
zostaje trudna dostępność części warowni (np. Olsztyn, Smoleń), większości skałek (np. Brama Twardowskiego) oraz jaskiń (Grota Łokietka, Jaskinia Ciemna), co wynika z reguły ze zbyt dużego nachylenia ścieżki. Część atrakcji jest jednak łatwo osiaggalna (m.in. zamki w Mirowie i Bobolicach, Pieskowa Skała), choć nie zawsze nachylenia są zgodne z zalecanymi normami. Dostosowane do potrzeb osób niepełnosprawnych są powiązane ze Szlakiem Orlich Gniazd znakowane trasy w rejonie Doliny Wodącej obok przysiółka Poduchowne niedaleko Strzegowej. Natomiast niedostępna jest większość atrakcji Ojcowskiego Parku Narodowego - osoby na wózkach mogą je podziwiać właściwie wyłącznie z drogi asfaltowej biegnącej dnem doliny Prądnika.

W opracowaniu Szlak Orlich Gniazd. Koncepcja rozwoju produktu turystycznego. Strategia komunikacji marketingowej 2012-2017 (2011) prawie w ogóle nie poświęca się miejsca nt. przystosowania szlaku czy związanych z nim walorów krajoznawczych do potrzeb osób niepełnosprawnych, chociaż niedostosowanie atrakcji turystycznych pod tym względem uznaje się w nim za jedno z zagrożeń dla przyszłego rozwoju szlaku. Strategia ta stawia głównie na osoby młode, sprawne fizycznie i wyróżniające się dobrą kondycją.

Poza wymienionymi znajduje się jeszcze ścieżka przystosowana do potrzeb osób z chorobami narządu wzroku, m.in. arboretum w Bolestraszycach, natomiast szlaki lub odcinki szlaków dla osób poruszających się na wózkach inwalidzkich w Bieszczadach i w Tatrach, przy czym ten drugi przypadek został ostatnio szczegółowiej omówiony w numerze 2/2012 kwartalnika „Tatry” (głównie: KOSUT 2012b).

\section{Doświadczenia czeskie}

W Republice Czeskiej szlaki przystosowane dla niepełnosprawnych są mniej liczne niż w Polsce, trzeba jednak zaznaczyć, że dzięki wyasfaltowaniu licznych dróg górskich osoby poruszające się na wózkach inwalidzkich mogą bez większych problemów dotrzeć daleko w głąb masywów górskich (choć czasem nachylenie trasy jest znaczne, co może powodować konieczność pomocy opiekuna). Jest to dobrze zauważalne zwłaszcza w czeskich Karkonoszach, gdzie dzięki drogom dojazdowym do schronisk turyści na wózkach mogą dostać się nawet w najwyższe partie gór. Najbardziej spektakularny jest przejazd Slezską cestą z położonych u podnóża gór Rybničnich 
Domków (część miejscowości Strážné), przez Světlý vrch i kapliczkę pod szczytem Lučni hory (1510 m n.p.m.), do leżącej na Równi pod Śnieżką Lučni boudy (1410 m n.p.m.). Podobnie jak po polskiej stronie Karkonoszy w czeskim parku narodowym wprowadzany jest program przystosowywania szlaków do potrzeb osób niepełnosprawnych. Górskie drogi asfaltowe przecinają również inne łańcuchy górskie Republiki Czeskiej, przy czym szczególnie dużo jest ich w Górach Izerskich, Górach Orlickich oraz przy granicy południowej, wzdłuż której ciągnie się tzw. signálka, służąca kiedyś do patrolowania granicy.

W Zelenej horze, północnej części Žd’áru nad Sázavou, pomiędzy dwoma stawami znajduje się wiele kulturowych walorów krajoznawczych, z których najważniejszy to wpisany na Listę Światowego Dziedzictwa UNESCO, założony na planie pięcioramiennej gwiazdy kościół pątniczy św. Jana Nepomucena. Stworzono tu dwie okólne ścieżki dydaktyczne (rys. 3), udostępniające wszystkie walory krajoznawcze Zelenej hory i okolicy, a zaczynające się w pobliżu wejścia do dawnego klasztoru cysterskiego, później zamienionego na pałac. Trasa A o długości 2,1 km obiega Bránský rybník, doprowadzając do dwóch obiektów zaprojektowanych przez wybitnego architekta czeskiego baroku Jana B. Santiniho Aichla: folwarku Lyra założonego na planie odpowiadającym nazwie i tzw. Dolnego Cmentarza. Natomiast trasa B o długości 2,6 km wiedzie wokół stawu Konvent, przedstawiając walory przyrodnicze (pomnik przyrody Louky u Černého lesa), widoki na pałac znad zbiornika wodnego oraz kościół św. Jana Nepomucena. Obie wymienione trasy są dostępne dla niepełnosprawnych ruchowo, jedynym wyjątkiem jest końcowy odcinek trasy B, gdzie przeszkodą jest śluza spiętrzająca wody stawu Konvent, ale przygotowano i oznaczono objazd uliczkami przyległego osiedla.

W przypadku trasy A dostępność dla osób na wózkach inwalidzkich wynika z wcześniej istniejącej infrastruktury - wykorzystuje ona chodniki i boczne drogi asfaltowe, przy czym wszystkie krawężniki, mogące stanowić przeszkodę, zostały obniżone. Natomiast przygotowując trasę B poczyniono już znaczne inwestycje skierowane wyłącznie do turystów, ze szczególnym uwzględnieniem turystów niepełnosprawnych. Zachowując kolejność zwiedzania, po minięciu założenia pałacowego i dawnych ogrodów, szlak prowadzi zachodnim zboczem doliny Stžskiego potoku, która na tym odcinku zalana jest wodami stawu Konvent. Na stromym odcinku sprowadzającym do doliny przygotowano specjalny zjazd (rampę), która ma kształt serpentyny ze spocznikami na zakrętach. W efekcie problem znacznego spadku 


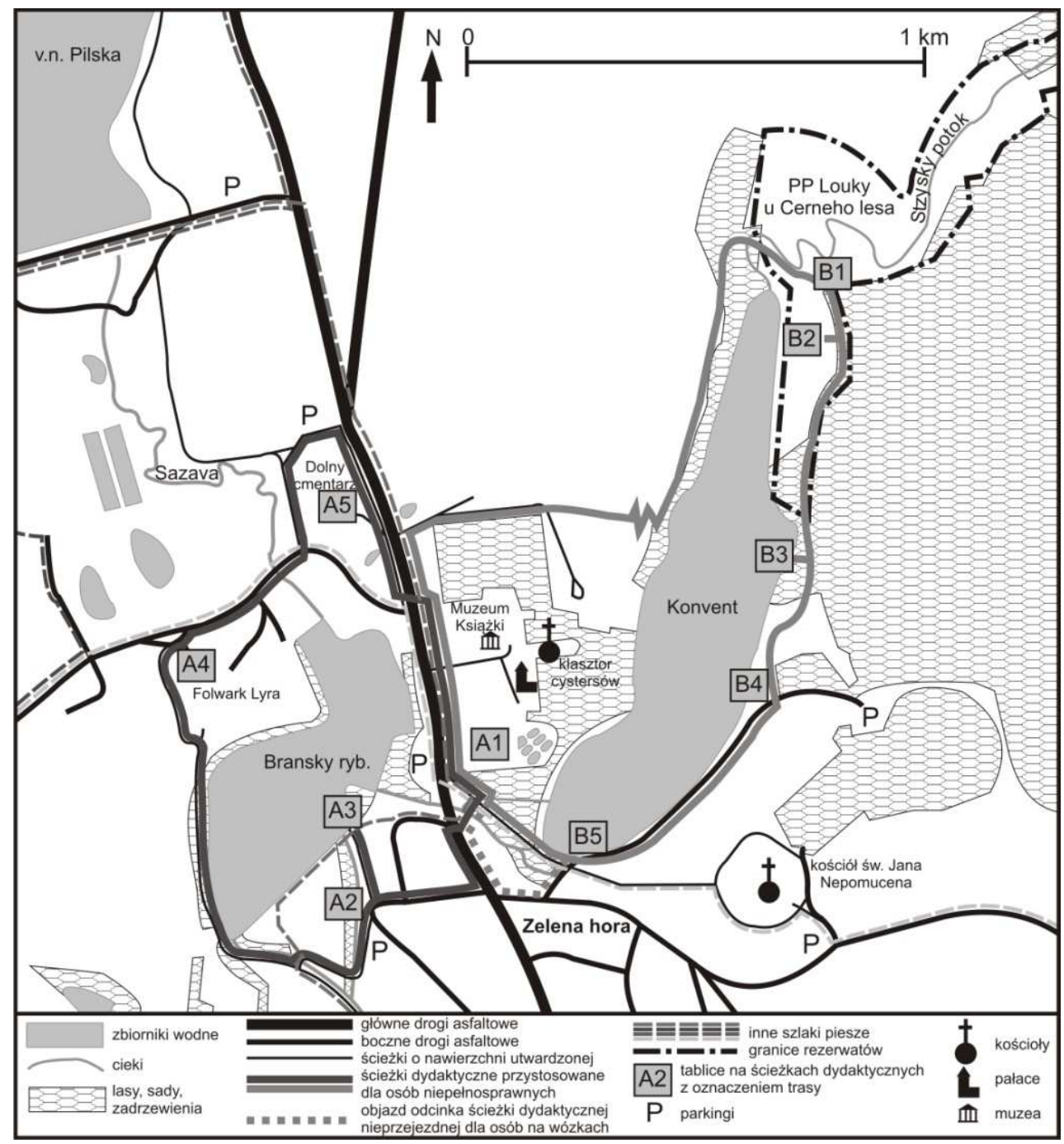

Rys. 3. Ścieżki dydaktyczne przystosowane do potrzeb osób niepełnosprawnych w Ždárze nad Sázavou Źródło: opracowanie własne

terenu został zniwelowany i nachylenie szlaku mieści się w zalecanych normach. Następnie szlak prowadzi mniej więcej w połowie wysokości zbocza po drewnianych pomostach z barierką od strony spadku (fot. 3), jedynie w kilku mniej stromych miejscach przygotowano wyrównaną ścieżkę ziemną. Trasa łagodnie opada na dno doliny, by mostkiem przeprawić się na 
drugą stronę Stžskiego potoku i wieść nadal po pomostach wśród rozlewisk cieku chronionych $\mathrm{w}$ ramach pomnika przyrody Louky u Černého lesa. Następnie trasa przechodzi na wschodnie zbocze doliny, gdzie także poprowadzona jest drewnianymi kładkami, przy czym przygotowano tu dwa krótkie odcinki boczne zakończone platformami widokowymi, z których również można podziwiać obszar chronionych łąk i brzegi stawu. Te dwie bocznice odznaczają się jednak gorszą dostępnością dla osób na wózkach, znajdują się na nich bowiem odcinki bardziej strome, co wynika z potrzeby przedostania się ze zbocza doliny na jej dno. Ostatecznie trasa B wyprowadza na asfaltową dróżkę u podnóża kościoła św. Jana Nepomucena, wiedzie do wspomnianej śluzy na Stžskim potoku, skąd osoby na wózkach inwalidzkich udają się do miejsca początkowego przez osiedle, a inni turyści aleją wzdłuż cieku wodnego.

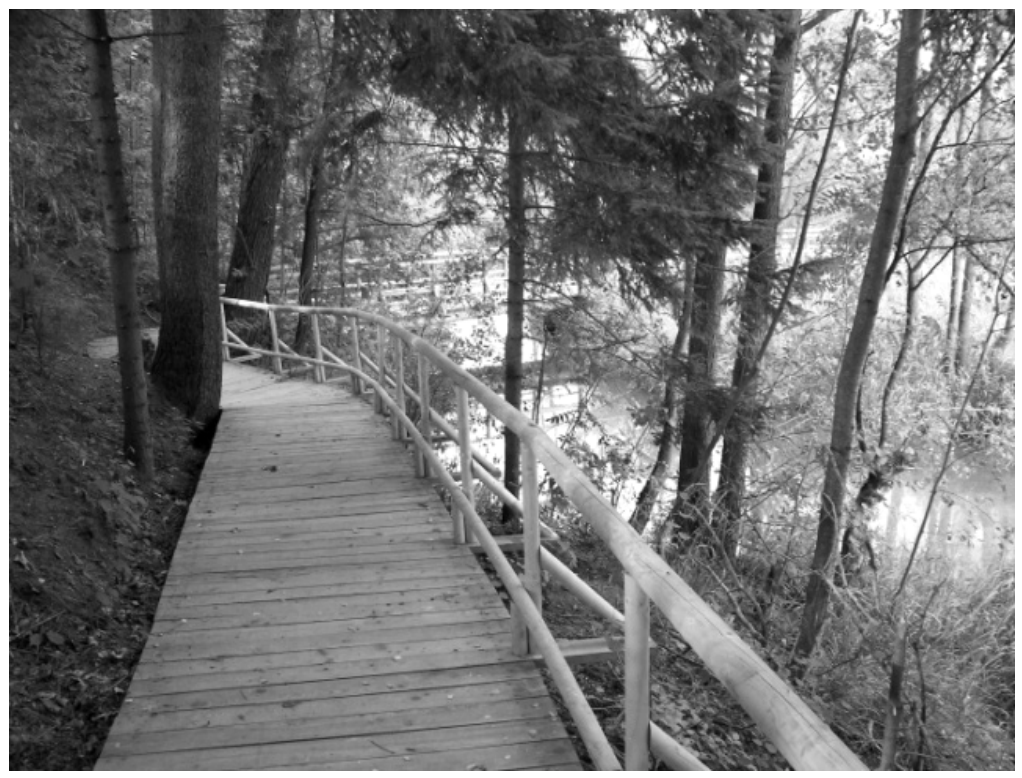

Fot. 3. Kładka nad Stžskim potokiem - część przystosowanej dla niepełnosprawnych trasy B w Žd’árze nad Sázavou (fot. K. Kołodziejczyk, 2011)

$\mathrm{Na}$ obu trasach znajduje się $\mathrm{w}$ sumie 10 miejsc zatrzymań $\mathrm{z}$ tablicami dydaktycznymi (po pięć na każdej), które niestety nie zostały wzbogacone w tekst pisany brajlem. Trasa A prowadzi w całości po drogach o sztucznej 
nawierzchni (asfalt, beton), natomiast na trasie B obok odcinków asfaltowych duży udział mają drewniane pomosty, pojawiają się również fragmenty ścieżek ziemnych. Na drugim szlaku obowiązuje zakaz jazdy rowerami, by uniknąć wypadku na relatywnie wąskich kładkach. Szerokość pomostów (około 1,5 m) umożliwia wygodny przejazd jednemu wózkowi, a co jakiś czas przygotowano rozszerzenia, gdzie wózki mogą się minąć. Całemu projektowi towarzyszy broszura promocyjna dostępna $\mathrm{w}$ centrum informacji turystycznej w ratuszu Žd'áru nad Sázavou, ponadto zamieszczona na internetowej witrynie miasta. Trzeba jednak zaznaczyć, że nie zawarto w niej bezpośrednio informacji, że oba szlaki są dostępne dla osób na wózkach inwalidzkich. Jedyną pośrednią informacją jest zamieszczony na mapce piktogram osoby na wózku przy objeździe odcinka trasy B przez jaz stawu Konvent.

\section{Próba stworzenia wzorca}

Należy pamiętać, że występują różne typy niepełnosprawności i każdy z nich wymaga nieco lub całkiem innego przystosowania odnośnie do szlaków turystycznych. Nie należy wiązać szlaków dla niepełnosprawnych wyłącznie z osobami poruszającymi się na wózkach inwalidzkich. Trasy skierowane do innych grup już się w Polsce pojawiły, czego dowodem są ścieżki dydaktyczne z infrastrukturą dla niewidomych w Górach Suchych i Stołowych. Najważniejsze jest stworzenie jakiejkolwiek oferty skierowanej do niepełnosprawnych, stąd w pierwszej kolejności wystarczą specjalnie przygotowane odcinki szlaków, natomiast dopiero w dalszej perspektywie dłuższe trasy czy nawet sieci szlaków. Niezależnie od rodzaju niepełnosprawności trasy nie powinny być prowadzone drogami dostępnymi dla ruchu samochodowego, należy również w miarę możliwości unikać skrzyżowań z takimi drogami. Przedstawione poniżej propozycje wynikają z obserwacji poczynionych na opisanych szlakach oraz ze wskazań literatury z zakresu urbanistyki i transportu (m.in. ZAZDROŻNY 2009). Autor planuje pogłębienie tematyki w oparciu o dalsze studia literaturowe.

W przypadku szlaków dla osób poruszających się na wózkach inwalidzkich najważniejszym elementem są drogi o odpowiednich parametrach. Powinny mieć szerokość co najmniej 1,2 m (przy takiej szerokości niezbędne 
są mijanki i bezwzględny zakaz poruszania się rowerzystów), przy czym najbardziej pożądana jest szerokość około $2 \mathrm{~m}$. Nachylenie podjazdów dłuższych niż 1,5 m nie powinno przekraczać $6 \%$, co umożliwia poruszanie się niepełnosprawnym na wózkach klasycznych i elektrycznych. W przypadku podjazdów krótszych możliwe są wyjątkowo większe nachylenia, natomiast na podjazdach dłuższych niż $9 \mathrm{~m}$ konieczne są spoczniki o długości co najmniej 1,4 m (ZAZDROŻNY 2009). Nachylenie poprzeczne ścieżki nie powinno przekraczać $2-6 \%$. Duże deniwelacje terenu mogą być pokonywane wyłącznie dzięki specjalnym rampom o zygzakowatym kształcie, także z odpowiednio rozmieszczonymi spocznikami. Nawierzchnia drogi powinna być pozbawiona luźnych kamieni i wyrównana, ale nie idealnie równa, co mogłyby powodować jej znaczną śliskość, zwłaszcza po opadach deszczu lub śniegu, bądź w przypadku zlodzenia. Rozwiązaniem tego problemu na terenie górskim $\mathrm{w}$ przypadku dróg biegnących $\mathrm{w}$ poprzek poziomic są plastikowe siatki, którymi pokrywa się całą lub część szerokości drogi, natomiast w przypadku dróg równoległych do poziomic - drewniane kładki o równej, dobrze utrzymanej nawierzchni. Na płaskim terenie nawierzchnia drogi może składać się z drobno pokruszonej skały (np. tłuczeń drogowy) z dużym udziałem gliny, przy czym całość musi być ugnieciona i wyrównana.

Wzdłuż ścieżki powinna ciągnąć się barierka o poręczach na wysokości dostosowanej do osób siedzących na wózkach, ale nie stanowiąca niebezpieczeństwa dla turystów pełnosprawnych, w tym narciarzy w przypadku zimowego wykorzystywania okolicy. By uniknąć zbytniej ingerencji w krajobraz, poręcz może pojawiać się tylko w miejscach bardziej niebezpiecznych (spadek terenu, przepaście). Aby tablice dydaktyczne były użyteczne dla osób na wózkach, niezbędne jest ich obniżenie, co może stanowić problem przy wspólnym ich użytkowaniu przez inne grupy turystów. W ogóle cała infrastruktura związana ze szlakami musi być dla osób niepełnosprawnych ruchowo odpowiednio przygotowana. Na pierwszy plan wysuwają się tu specjalne toalety (większe, z szerszymi wejściami i uchwytami) oraz dostępne schroniska turystyczne, co jest $z$ reguły problematyczne, biorąc pod uwagę zabytkowy charakter większości z nich.

Dla osób niewidzących lub słabo widzących przy wejściach na szlaki i przy poszczególnych atrakcjach powinny być dostępne informacje przedstawione pismem Braille'a lub w sposób dźwiękowy. W pierwszym przypadku mogą to być osobne tablice przeznaczone wyłącznie dla tej grupy lub tylko dodatkowy tekst brajlem na zwykłych tablicach dydaktycznych. 
Ciekawym rozwiązaniem są też rzeźbione elementy, które można odkrywać dotykiem (np. plastyczne mapy rzeźby terenu), oraz tzw. ogrody zmysłów. Jeśli chcemy przekazywać informacje w sposób dźwiękowy, rozwiązaniem są różnego typu odtwarzacze (np. audio-guide), przy czym ze względu na znaczny koszt mogą one być wykorzystywane tylko w popularniejszych miejscach, a względy techniczne i dotychczasowe doświadczenie wiążą je raczej z obiektami kulturowymi i miastami, a nie z terenami wiejskimi i górskimi. Szlaki dla osób niewidzących lub słabo widzących także muszą odznaczać się w miarę wyrównaną nawierzchnią, małymi lub co najwyżej średnimi nachyleniami oraz odpowiednią szerokością, tak by umożliwić swobodne poruszanie się obok siebie dwóch osób (przewodnika $\mathrm{z}$ niewidomym). Do minimum muszą być ograniczone przeszkody, takie jak wystające korzenie drzew, rynny odwadniające, progi, schody, a te nie do uniknięcia powinny być oznaczone w sposób wyróżniający się. W USA istnieją szlaki, na których niewidomy jest prowadzony przez zawieszoną wzdłuż linę (General Design Guidelines... 2007).

Osoby z uszkodzonym narządem słuchu właściwie nie wymagają specjalnych przygotowań na szlakach, chyba że chcemy im jednocześnie przekazywać jakąś wiedzę. Poszukiwania technicznych rozwiązań, które niwelowałyby bariery między językiem fonicznym i migowym w przekazywaniu informacji krajoznawczych i w zakresie organizacji wyjazdów turystycznych, podjęła się A. ZAJADACZ (m.in. 2007, 2008, 2010), przedstawiając koncepcję systemu informacji turystycznej dla osób niesłyszących, dostępnego w warunkach stacjonarnych i terenowych. Rozwiązanie opiera się na coraz ostatnio popularniejszych przenośnych elektronicznych przewodnikach turystycznych (typu iGuide), które obok standardowych wersji językowych byłyby wyposażone też $\mathrm{w}$ polski język migowy (wyświetlany na ekranie). W przypadku innych rodzajów niepełnosprawności potrzeba ewentualnych przystosowań i ich charakter zależą od cech indywidualnych, które mogą się znacznie różnić, stąd niemożliwe jest przedstawienie żadnych ogólnych wzorców. Osoby niepełnosprawne wymagają również zupełnie innego przewodnictwa. Tematyka ta nie będzie tu jednak rozwijana, a pewne informacje w tym zakresie przedstawił Ł. KosUT (2012a).

Organizacje związane z osobami niepełnosprawnymi wskazują aby unikać standardowego określania tras odpowiednio przygotowanych na potrzeby tej grupy osób jako „szlaków dla niepełnosprawnych”. Takie określenia według nich niepotrzebnie segregują turystów, podkreślając różnice między 
osobami pełnosprawnymi i niepełnosprawnymi. Ponadto nie są precyzyjne i nie określaja jakiego rodzaju niepełnosprawności przystosowanie dotyczy. Organizacje te postulują aby każda z tras była dokładnie charakteryzowana poprzez określenie rodzaju nawierzchni, średnich i maksymalnych nachyleń oraz minimalnych szerokości drogi, istnienia potencjalnych przeszkód (kład$\mathrm{ki}$, schody, korzenie, inne nierówności nawierzchni) oraz udogodnień (pochylnie, barierki, wygodny parking, toalety przystosowane dla niepełnosprawnych). Warto też określić dostępność schronisk i miejsc odpoczynkowych. Dzięki takim informacjom niepełnosprawni bądź ich opiekunowie mogą sami ocenić, czy będą w stanie pokonać konkretną trasę i czy może się to odbyć samodzielnie lub z pomoca, podobnie jak pełnosprawni turyści decydują o podjęciu wędrówki szlakiem o konkretnym poziomie trudności.

$\mathrm{W}$ związku z tymi propozycjami rodzi się jednak kilka wątpliwości. Trudno jednoznacznie określić potrzebną dokładność przekazywanych danych o szlakach, gdyż - zwłaszcza w przypadku dłuższych tras - ilość informacji może być znaczna. Wszystkie charakterystyki muszą być dostępne już na etapie planowania podróży - trzeba poprzez różne dostępne media (m.in. przewodniki książkowe, Internet) dotrzeć do poszczególnych grup osób niepełnosprawnych. Ponadto trudne może być przedstawienie całego zestawu danych w terenie, co wymagałoby tablic znacznych rozmiarów. Zasób wiedzy o szlakach, by nie narażać niepełnosprawnych turystów na niebezpieczeństwo lub niedogodności, musiałby być na bieżąco uaktualniany, gdyż - zwłaszcza na terenach górskich - nawierzchnia szlaków może ulegać zmianom z dnia na dzień (erozja pod wpływem intensywnych opadów odsłaniająca kamienie, skalne podłoże lub korzenie). Ostatnia wątpliwość dotyczy tego, czy wszyscy niepełnosprawni turyści i ich opiekunowie będą w stanie odpowiednio zinterpretować przekazywane informacje. Często bowiem ludzie są skłonni podejmować ryzyko i nie w pełni zdają sobie sprawę z własnych możliwości.

\section{Podsumowanie}

Jedną z przyczyn niskiego poziomu uczestnictwa osób niepełnosprawnych w turystyce jest niedostateczna ilość odpowiedniej dla nich bazy turystycznej, z drugiej jednak strony ważną barierę stanowi brak informacji o istnieniu 
takiej przystosowanej do ich potrzeb infrastruktury, m.in. o specjalnych trasach turystycznych. Właściwie w Polsce i Republice Czeskiej nie istnieją odpowiednio rozpropagowane szlaki dla omawianej grupy osób. Wydano zaledwie kilka przewodników turystycznych skierowanych do niepełnosprawnych, przy czym w większości dotyczą one obszarów zurbanizowanych. Potwierdzeniem powyższego są analizowane szlaki - trudno znaleźć informacje nie tylko o sposobie ich przystosowania dla niepełnosprawnych, ale często nawet o ich istnieniu. W przypadku polskich szlaków tylko czasem są to krótkie wzmianki w Internecie, natomiast przedstawione czeskie szlaki są trochę lepiej promowane, choć i tu skąpa jest informacja o ich dostępności dla osób na wózkach inwalidzkich.

Praca pokazała, że szlaki dla niepełnosprawnych realizują część stawianych postulatów, często jednak projekty pozostają niedopracowane, a na pewno niedostatecznie rozpropagowane.

\section{BIBLIOGRAFIA}

General Design Guidelines E Schedule of Design Elements For the Haw River Trail. Conceptual Greenway Master Plan. From the Indian Valley Golf Course to Glencoe Mill Village, 2007, Piedmont

Triad Council of Governments, North Carolina.

Instrukcja znakowania szlaków turystycznych, 2007, Wyd. PTTK „Kraj”, Warszawa.

KosUT Ł., 2012a, Inne przewodnictwo, "Tatry” 2(40), TPN, s. 70-73.

Kosut Ł., 2012b, Tatry dla wszystkich, „Tatry” 2(40), TPN, s. 56-59.

LIJEWSKI T., MIKUŁOWSKI B., WYRZYKOWSKI J., 2002, Geografia turystyki Polski, PWE, Warszawa.

SKALSKA T., 2004, Turystyka osób niepetnosprawnych. Ograniczenia i możliwości rozwoju, Wyższa Szkoła Hotelarstwa, Gastronomii i Turystyki, Warszawa.

Szlak Orlich Gniazd. Koncepcja rozwoju produktu turystycznego. Strategia komunikacji marketingowej 2012-2017, 2011, Związek Gmin Jurajskich, Agencja Promocji Miast i Regionów, Kraków.

ZAJADACZ A., 2007, Propozycja przekazu informacji o i na szlakach turystycznych osobom niestyszacym przy wykorzystaniu technik wizualnych, [w:] P. Kuleczka (red.), Szlaki turystyczne a przestrzeń turystyczna, Wyd. PTTK „Kraj”, Warszawa, s. 97-102.

ZAJADACZ A., 2008, Aktywizacja osób niestyszacych poprzez wykorzystanie multimedialnego systemu informacji turystycznej, [w:] R. Grzywacz (red.), Turystyka i rekreacja szansq rozwoju aktywności społecznej, Wyższa Szkoła Informatyki i Zarządzania, Rzeszów, s. 139-148.

ZAJADACZ A., 2010, SITex and SITur the idea behind the Project and its target group, [w:] A. Zajadacz (red.), The SITex and SITur programs as tools designed to provide information to visitors and tourists using the Polish Sign Language, Wyd. Naukowe UAM, Poznań (CD), s. 21-22.

ZADROŻNY P., 2009, Dostępna komunikacja miejska, Fundacja Instytut Rozwoju Regionalnego, Kraków. 